\title{
Comprehension of Pamphlet Developed on Composting from Agriculture and Animal Waste
}

\author{
Rashmi Durgapal* and Rajshree Upadhyay \\ Department of Extension Education and Communication Management, College of Community \\ and Applied Sciences, MPUAT, Udaipur (Rajasthan), India \\ *Corresponding author
}

\begin{tabular}{|c|c|}
\hline & A B S T R A C T \\
\hline $\begin{array}{l}\text { K e y w o r d s } \\
\text { Composting, } \\
\text { Comprehension, } \\
\text { Field testing, } \\
\text { Pamphlet }\end{array}$ & \multirow{3}{*}{$\begin{array}{l}\text { Raw organic materials such as animal wastes, crop residues, food garbage enhance } \\
\text { their suitability for application to the soil as a fertilizing resource, after their } \\
\text { conversion through the composting process. The present study examined } \\
\text { comprehension of a pamphlet developed on composting from agriculture and animal } \\
\text { waste. For this purpose, a sample of } 30 \text { literate rural women having primary to upper } \\
\text { education, was selected from a randomly selected Girwapanchayatsamiti of the } \\
\text { Udaipur district of Rajasthan state. The data was collected with the help of a self- } \\
\text { structured questionnaire by personal interview technique. Data analysis revealed the } \\
\text { overall comprehension of the pamphlet was found to be very good with mean per cent } \\
\text { score } 99 \text {. The title of the pamphlet krishiaurpashuapshist se khaad banana was } \\
\text { understood by all the respondents while content and illustrations were comprehended } \\
\text { by } 90-100 \% \text { and } 86.67-100 \% \text { respondents, respectively. }\end{array}$} \\
\hline Article I & \\
\hline $\begin{array}{l}\text { Accepted: } \\
\text { 17 September } \\
\text { Available Onli }\end{array}$ & \\
\hline
\end{tabular}

\section{Introduction}

Waste management is an important driving force for community health. Whether it is agriculture or animal waste an untreated waste is always harmful for human health and the environment. In rural parts of India the major occupation is agriculture and allied sector such as livestock thus the everincreasing quantity of agriculture waste such as crop remaining, straw, dead leaves; and animal waste such as dung, urine is a growing environmental concern. The animal waste generated in rural areas is used by the people mostly in agriculture fields without any treatment. Waste material especially the crop residues are burnt in the field which led to environmental issues such as $\mathrm{Smog}$, emission of greenhouse and other gases, loss of nutrients and elevates soil temperature causing death of beneficial soil organisms. According to the Indian Ministry of New and Renewable Energy (MNRE), India generates on an average 500 Million tons (Mt here after) of crop residue per year. Among different crops, cereals generate maximum residues (352 Mt), followed by fibres (66 Mt), oilseeds (29 Mt), pulses (13 Mt) and sugarcane (12 Mt). Cereal crops (rice, wheat, maize, millets) contribute $70 \%$, while rice 
crop alone contributes $34 \%$ to the crop residues. Grower et al., (2015) concluded that most of the respondents $(96 \%)$ practiced agricultural crop residue burning after crop harvesting and 90 per cent of them were well aware regarding air pollution caused by residual burning. However, they were unaware about air pollution related health problems. The farmers were also unaware about the negative impacts of residue burning on soil quality. Thus there is a need to create awareness among grass root level among people involved in agriculture and allied activities. It is necessary to enhance the knowledge of people, engaged in agriculture and allied activities, about different ways to effectively utilize the residues.

The direct use of animal waste in fields does not generate effective results. For effective residue management, composting, biochar production and mechanization are a few effective sustainable techniques that can help to curtail the issue while retaining the nutrients present in the crop residue in the soil (Bhuvneshwari et al., 2019). If the waste is converted into any type of compost it will not only enhance the nutritious value of the soil but also ensure the effective utilization of waste. Composting can be an attractive as it is a low-cost technology. The treated nature of compost makes it more stable than untreated or partially treated wastes. Vermicomposting represents an alternative approach in waste management for handling organic residuals as the material is neither landfilled nor burned but is considered a resource that may be recycled. It is compatible with sound environmental principles that value conservation of resources and sustainable practices (Alok et al., 2008).

Media is a powerful tool to convey any idea, fact or feeling among the larger group of people. It has immense potential to transform the society. Media available in different form i.e. electronic or print media hold power to bolster the society towards development. However, being the cheapest and very reliable medium, print media hold a key position among mass media (Ran et al., 2017).

Print media include newspaper, magazine, books, booklet, brochures, pamphlets, flyers, memos, letters, etc. The pamphlets are considered effective for public education. According to Darabi et al., (2015), pamphlet as an educational tool has a significant effect on increasing the knowledge. Being easy and cost-effective, this educational tool can be put on the top priorities for educational interventions. Ali et al., (2017) also observed significantly increased knowledge of people by use of educational pamphlet regardless of their socio-demographic characteristics.

The pamphlet developed on different composting methods to better utilize the agriculture and animal waste, with specific features viz. easy readability and comprehension so that these can be easily understood by the readers with minimum education qualification. The preferred language was Hindi as the majority of readers of agriculture and allied occupation can speak and understand Hindi language easily. Salathia et al., (2013) also suggested that the information should be made available in vernacular language to the farmers in far flung areas.

The designed pamphlet can be used as ready reference for awareness generation to safeguard the community health and environment. For this, pamphlet was field tested by a small sample before its wider publication.

\section{Materials and Methods}

The study was conducted in randomly selected Girwapanchayatsamiti of Udaipur 
district of Rajasthan. Two villages namely Kanpur and BhoiyonkiPacholi were chosen from the selected panchayatsamiti. A sample of 30 literate rural women (15 from each village), having primary to upper education, was taken from both the selected villages for testing the comprehension of developed pamphlet. A self-structured questionnaire was prepared and personal interview technique was used for data collection.

\section{Results and Discussion}

\section{Designing of pamphlet}

The pamphlet on comprehension from agriculture and animal waste was designed after collecting appropriate content from available literature. The collected content was approved by the subject matter specialists. After that, the content was organized in appropriate layout and pamphlet was designed using graphic designing software i.e. Corel Draw.

\section{Evaluation of pamphlet by the experts}

Apanel of experts was selected from relevant field and the designed pamphlet was given to them for evaluation on various criteria i.e. relevance to topic, subject matter coverage, accuracy, language, layout, subtitle, continuity/ sequence, illustration, size of pamphlet and overall presentation.

The mean weighted score for all criteria ranged between 3.9 and 4.6 out of 5 . The overall mean weighted score of the pamphlet was 4.21 which indicate that the pamphlet was evaluated very good by the experts. The detail regarding evaluation of pamphlet by the experts is presented in Figure 1.

\section{Comprehension of pamphlet by the respondents}

The designed pamphlet was comprehended by randomly selected 30 literate rural women having primary to upper primary education. The pamphlet contained one title, 56 key messages and 9 illustrations in the content. The pamphlet covered information about concept, importance, advantages, different methods of composting such as farm yard manure (FYM), pot manure, vermiwash, nadep compost, vermicompost and compost tea and considerations while preparing compost.

Table.1 Comprehension of messages in pamphlet on composting from agriculture and animal waste

\begin{tabular}{|c|c|c|c|}
\hline S. No. & Key messages & Frequency & Percentage \\
\hline 1. & $\begin{array}{l}\text { Compost manure can be prepared by } \\
\text { decomposition of agriculture and animal waste }\end{array}$ & 28 & 93.33 \\
\hline 2. & Importance of composting & 30 & 100 \\
\hline 3. & $\begin{array}{l}\text { Methods of composting: FYM, pot manure, } \\
\text { nadep compost, vermiwash, vermicomposting } \\
\text { and compost tea. }\end{array}$ & 30 & 100 \\
\hline 4. & Considerations while preparing compost & 27 & 90 \\
\hline 5. & Advantages of compost manure & 30 & 30 \\
\hline
\end{tabular}


Table.2 Comprehension of messages related to FYM and pot manure preparation $n=30$

\begin{tabular}{|c|c|c|c|}
\hline S. No. & Key messages & Frequency & Percentage \\
\hline \multirow[t]{9}{*}{1.} & Farm yard manure & & \\
\hline & i. Importance of FYM & 27 & 90 \\
\hline & $\begin{array}{l}\text { ii. Animal dung, urine, litter are raw material } \\
\text { required for FYM preparation }\end{array}$ & 30 & 100 \\
\hline & iii. Method of FYM preparation & & \\
\hline & a) Preparation of trench & 30 & 100 \\
\hline & b) Collection of household waste, litter as a pile & 30 & 100 \\
\hline & $\begin{array}{l}\text { c) Spread raw material from pile under the animals } \\
(2.5 \mathrm{~kg} \text { /animal })\end{array}$ & 29 & 96.67 \\
\hline & d) Process of filling raw material in trench & 29 & 96.67 \\
\hline & $\begin{array}{l}\text { iv. Filling of second trench after the first trench is full } \\
\text { till then first trench manure is ready to be used }\end{array}$ & 30 & 100 \\
\hline \multirow[t]{8}{*}{2.} & Pot manure & & \\
\hline & i. Importance of pot manure & 30 & 100 \\
\hline & $\begin{array}{l}\text { ii. Fresh cow dung, cow urine, water, jaggery, and } \\
\text { clay pots are required to prepare pot manure }\end{array}$ & 30 & 100 \\
\hline & iii. Method of pot manure preparation & & \\
\hline & a) Mixing raw material in pot & 30 & 100 \\
\hline & b) Packing pot with cloth and clay & 30 & 100 \\
\hline & c) Eight days' time required for preparation & 30 & 100 \\
\hline & iv.Mixing of ready compost in water and then using it & 30 & 100 \\
\hline
\end{tabular}

Table.3 Comprehension of messages related to nadep compost and vermiwash $n=30$

\begin{tabular}{|l|l|c|c|}
\hline S. No. & \multicolumn{1}{|c|}{ Key messages } & Frequency & Percentage \\
\hline 1. & $\begin{array}{l}\text { Nadep compost } \\
\text { i. Usefulness of nadep composting }\end{array}$ & 29 & 96.67 \\
\hline $\begin{array}{l}\text { ii. Dung, grass, garbage, finely clay soil are } \\
\text { essentials for preparation of nadep composting }\end{array}$ & 30 & 100 \\
\hline $\begin{array}{l}\text { iii. Method of compost preparation } \\
\text { a) Construction of airy tank }\end{array}$ & 30 & 100 \\
\hline b) Wet tank walls with dung solution & 30 & 100 \\
\hline c) Filling of raw material in tank upto 6 inches & 30 & 100 \\
\hline d) Sprinkling of dung solution over filled raw & 30 & 100 \\
\hline $\begin{array}{l}\text { e) Spreading of 50-60 kg soil } \\
\text { f) Repeat the process and fill in the whole tank }\end{array}$ & 29 & 96.67 \\
\hline g) Seal the filled material with thick layer of soil & 30 & 100 \\
\hline h) Check readiness of compost & 30 & 100 \\
\hline iv. Time required for nadep compost preparation is & 30 & 100 \\
\hline
\end{tabular}




\begin{tabular}{|c|c|c|c|}
\hline & v. Before use, sieve the prepared compost & 29 & 96.67 \\
\hline \multirow[t]{11}{*}{2.} & Vermiwash & & \\
\hline & i. Importance of vermiwash & 28 & 93.33 \\
\hline & $\begin{array}{l}\text { ii. Earthworms, dung, sand, pitcher are essentials for } \\
\text { vermiwash preparation }\end{array}$ & 30 & 100 \\
\hline & iii.Method of preparation & & \\
\hline & a) Making a hole in pot and inserting pipe on it & 30 & 100 \\
\hline & b) Filling of raw material in a pot & 30 & 100 \\
\hline & c) Leaving earthworms in pot & 30 & 100 \\
\hline & d) Filling of water in another pot & 30 & 100 \\
\hline & e) Hanging both the pots through rope & 30 & 100 \\
\hline & f) Collection of prepared vermiwash after $15-20$ days & 29 & 96.67 \\
\hline & iv. Use vermiwash by mixing ten times water & 28 & 93.33 \\
\hline
\end{tabular}

Table.4 Comprehension of messages related to vermicompost and compost tea $n=30$

\begin{tabular}{|c|c|c|c|}
\hline S. No. & Key messages & Frequency & Percentage \\
\hline \multirow[t]{14}{*}{1.} & Vermicompost & & \\
\hline & i. Importance of vermicompost & 30 & 100 \\
\hline & $\begin{array}{l}\text { ii. Raw materials are animal dung, earthworms, } \\
\text { grass, leaves etc. }\end{array}$ & 30 & 100 \\
\hline & iii. Method of preparation & & \\
\hline & a) Preparation of shed & 30 & 100 \\
\hline & b) Preparation of bed & 30 & 100 \\
\hline & c) Filling of raw material & 29 & 100 \\
\hline & $\begin{array}{l}\text { d) Spread rotten cow dung manure over raw material } \\
\text { and make it wet }\end{array}$ & 29 & 96.67 \\
\hline & e) Spreading of earthworms over filled material & 30 & 100 \\
\hline & f) Spread cow dung and agriculture waste & 29 & 96.67 \\
\hline & $\begin{array}{l}\text { g) Sprinkling of water over each layer for } \\
\text { maintaining moisture }\end{array}$ & 30 & 100 \\
\hline & h) Cover the bed with gunny bags & 30 & 100 \\
\hline & i) Check readiness of compost & 30 & 100 \\
\hline & $\begin{array}{l}\text { iv. Time required for vermicompost preparation is } \\
45-60 \text { days }\end{array}$ & 30 & 100 \\
\hline \multirow[t]{7}{*}{2.} & Compost Tea & & \\
\hline & $\begin{array}{l}\text { i. A liquid solution of compost which requires ready } \\
\text { compost and pitcher for its preparation }\end{array}$ & 28 & 93.33 \\
\hline & ii. Method of compost tea preparation & & \\
\hline & a) Putting ready compost into a cloth bale & 28 & 93.33 \\
\hline & b) Hang the cloth bale in a water filled pot & 30 & 100 \\
\hline & c) Stir the solution daily for at least 7 days & 30 & 100 \\
\hline & iii. Use compost tea by mixing in water & 29 & 96.67 \\
\hline
\end{tabular}


Table.5 Comprehension of illustrations in the pamphlet on composting from agriculture and animal waste $n=30$

\begin{tabular}{|c|l|c|c|}
\hline S. No. & \multicolumn{1}{|c|}{ Illustrations } & Frequency & Percentage \\
\hline 1. & Compost & 28 & 93.33 \\
\hline 2. & $\begin{array}{l}\text { Woman mixing raw materials required for pot } \\
\text { manure preparation }\end{array}$ & 30 & 100 \\
\hline 3. & Airy tanks for nadep compost preparation & 28 & 93.33 \\
\hline $\mathbf{4 .}$ & $\begin{array}{l}\text { Hanging of pitchers for preparation of } \\
\text { vermiwash }\end{array}$ & 26 & 86.67 \\
\hline $\mathbf{5 .}$ & Ready vermiwash & 27 & 90 \\
\hline $\mathbf{6 .}$ & Beds in vermicompost unit & 30 & 100 \\
\hline $\mathbf{7 .}$ & Single vermicompost bed & 27 & 90 \\
\hline $\mathbf{8 .}$ & Pot for preparation of compost tea & 30 & 100 \\
\hline $\mathbf{9 .}$ & Ready compost tea & 26 & 86.67 \\
\hline
\end{tabular}

Fig.1 Evaluation of developed pamphlet on various criteria by the experts

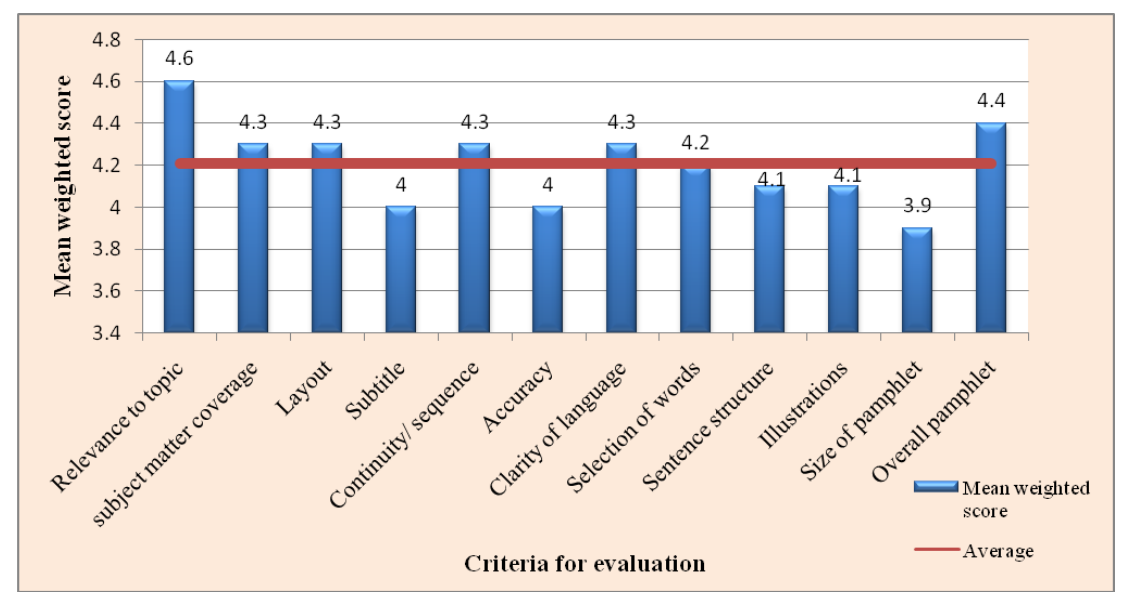

\section{Comprehension of title}

The title of the pamphlet i.e. krishiaurpashuapshist se khaad banana was comprehended by all the respondents which indicates excellent comprehension of the title.

\section{Words perceived difficult to comprehend}

The words included in the content such as vermiwash, nadep, vermikhaad, nitrogen and jeewanu were found difficult to comprehend by very few respondents $(3.33-6.67 \%)$ as they are not generally used words. Rest all the words included in the pamphlet, were completely understood by all the respondents.

\section{Comprehension of content}

Pamphlet on composting from animal and agriculture waste covers information related to various methods and consideration while compost preparation. Data presented in Table 1-4 depict comprehension of messages included in the pamphlet by the respondents. There are total 56 messages included out of which 38 messages were understood by all the respondents and rest 18 messages were understood by most of the respondents (90$96.67 \%$ ). 
The messages presented in Table 1 on importance of composting, methods and advantages of compost manure were understood by all the respondents. Remaining two messages were also understood by majority of the respondents (90-93.33\%).

Table 2 includes total thirteen messages related to farm yard manure and pot manure. The message on importance of FYM was understood by 90 per cent respondents while the raw material required was perceived as easy to understand by all the respondents. Similarly, the preparation of FYM includes certain steps viz. preparation of trench, collection of raw material, spreading the material under animals and then filling it into trenches. All these messages related to preparation method were comprehended by majority of the respondents (96.67-100\%). Rest of the respondents was not familiar with the nutrients such as nitrogen, potash mentioned under importance which resulted in lack of comprehension.

Another form of compost i.e. pot manure was written in six key messages which included the importance, raw material and method of preparation of pot manure. All these messages were comprehended by all the respondents (Table 2).

Data presented in Table 3 cover messages related to preparation of nadep compost and vermiwash. For nadep compost, out of twelve messages eight were completely understood by all the respondents. Rests four messages were comprehended by $93.33-96.67 \%$ respondents.

Further, the findings elucidate the comprehension of messages related to vermiwash by the respondents. All the messages were understood by all the respondents $(100 \%)$ except three messages i.e. 'importance of vermiwash', 'collection of prepared vermiwash after 15-20 days' and 'use vermiwash by mixing ten times water'. These three messages were comprehended by 93.33-96.67\% respondents.

The process of vermicompost preparation includes certain steps such as shed preparation, bed preparation, filling of raw material, spreading earthworms, dung manure with agriculture waste, sprinkling of water, covering of the beds, checking readiness with 45-60 days' time for compost preparation. Perusal of Table 4 reveals that the messages related to importance, raw material, preparation method and time required for vermicompost, were understood by $96.67-$ $100 \%$ respondents. Further, the data indicate that all the five key messages related to compost tea, its preparation and use were understood by majority of the respondents (93.33-100\%).

\section{Comprehension of illustrations}

Data in Table 5 reveal the comprehension of illustrations used in the pamphlet by the respondents. It was found that all the nine illustrations were understood by 86.67 to 100 per cent respondents. The reason behind this might be that the included illustrations were either related to preparation process or image of final product which were unfamiliar for them initially.

\section{Overall comprehension}

For overall comprehension, the pamphlet obtained mean per cent value 99 which is very close to maximum score i.e. 100. This indicates a very good comprehension of pamphlet. The reason for such finding could be use of simple language, easily understandable and self-explanatory content, appropriate and easy illustrations. Some of the respondents had previously attended training related to composting which might have 
helped them in better understanding of the content.

In conclusion the pamphlet developed on 'Composting from agriculture and animal waste' was evaluated as very good by the experts with mean weighted score 4.21. The comprehension of title, content and illustration of pamphlet were also found to be very good. Thus the pamphlet can be usedas standardized educational materialfor generating awareness and increasing knowledge on preparing different forms of compost manure for better utilization of agriculture and animal waste.

\section{References}

Ali, A. N., N. K. Ping, S. K. Prajapati, M.Padampriya, Z. A. Nazer and Sarriff, A. 2017. Development and validation of educational pamphlet in prevention of Human Papilloma virus (HPV) infection among age eligible adults for HPV vaccination in Kedah State, Malaysia. MOJ Bioequivalence \& Bioavailability. 4: 1-7.

Alok, A., A. K. Tripathi and Soni, P. (2008). Vermicomposting: A Better Option for Organic Solid Waste Management. Journal of Human Ecology. 24: 59-64.

Bhuneshwari, S., H. Hettiarachchi and Meegoda, J. N. 2019. Crop residue burning in India: Policy challenges and potential solutions. International Journal of Environmental Research and Public Health.16: 832.

Darabi, L., F. A. Shokravi and Ghaffari, M. 2015. Assessment of designed pamphlet of osteoporosis knowledge of girl students. Health Education and Health Promotion (HEHP).3: 27-36.
Durgapal, R. 2018. Development of pamphlets related to Environmental Sanitation for rural women. M.Sc. Thesis submitted to Maharana Pratap University of Agriculture \& Technology, Udaipur, Rajasthan.

Grover, D., P. Kaur and Sharma, H. R. 2015. Possible reasons and farmers awareness towards crop residue burning: an overview and a case study from Mirzapur village of Kurukshetra district, India. Environment \& We An International Journal of Science and Technology. 10: 75-85.

National Policy for Management of Crop Residue. Ministry of Agriculture, Government of India.2014. Cited from http://agricoop.nic.in/sites/default/

files/NPMCR_1.pdf retrieved on September 4, 2020.

Ran, S., S. K. Verma and Lal, M. 2017. Empowerment of rural women by development of media as a printed booklet on vegetable cultivation for promoting nutritional security. In: Compendium on Nutrition-sensitive Agriculture: Changing Role of Extension. Society of Extension Education, Agra. Cited from http://www.seea.org.in/neec2017/Compendi um-NEEC-2017.pdf retrieved on August 15, 2020.

Salathia, P. S., P. Kumar, N. Paul and Ali, L. 2013. Problems faced by organic farmers in hilly areas of Udhampur district in Jammu region. Indian Journal of Extension Education and Rural Development.21: 5559.

Sharma, R. 2009. Development and field testing of instructional material on 'Entrepreneurship development' for rural women. Ph.D. Thesis submitted to MaharanaPratap University of Agriculture \& Technology, Udaipur, Rajasthan.

\section{How to cite this article:}

Rashmi Durgapal and Rajshree Upadhyay. 2020. Comprehension of Pamphlet Developed on Composting from Agriculture and Animal Waste. Int.J.Curr.Microbiol.App.Sci. 9(10): 21452152. doi: https://doi.org/10.20546/ijcmas.2020.910.261 